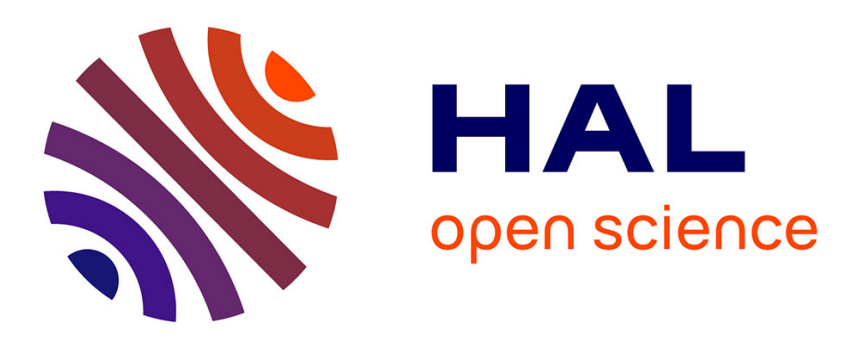

\title{
Minimization of eddy current losses in a straight rectangular cross section conductor
}

Xavier Margueron, Jean-Pierre Keradec, Anh Tuan Phung, Olivier Chadebec, Gérard Meunier

\section{- To cite this version:}

Xavier Margueron, Jean-Pierre Keradec, Anh Tuan Phung, Olivier Chadebec, Gérard Meunier. Minimization of eddy current losses in a straight rectangular cross section conductor. IEEE Conference on Electromagnetic Field Computation 2006, Apr 2006, Miami, United States. hal-00193721

\section{HAL Id: hal-00193721 \\ https://hal.science/hal-00193721}

Submitted on 12 Feb 2009

HAL is a multi-disciplinary open access archive for the deposit and dissemination of scientific research documents, whether they are published or not. The documents may come from teaching and research institutions in France or abroad, or from public or private research centers.
L'archive ouverte pluridisciplinaire HAL, est destinée au dépôt et à la diffusion de documents scientifiques de niveau recherche, publiés ou non, émanant des établissements d'enseignement et de recherche français ou étrangers, des laboratoires publics ou privés. 


\title{
Minimization of Eddy Current Losses in a Straight Rectangular Cross Section Conductor
}

\author{
Xavier Margueron, Jean-Pierre Keradec, Tuan Phung Anh, Olivier Chadebec, Gérard Meunier \\ Laboratoire d'Electrotechnique de Grenoble \\ INPG/UJF UMR-CNRS 5529, ENSIEG, B.P. 46, \\ 38402 Saint-Martin-d'Hères Cedex, France \\ xavier.margueron@leg.ensieg.inpg.fr
}

\begin{abstract}
To reach the goal mentioned in the title, an intuitive solution using two pieces of ferrite is first proven to be effective. Then, ferrite is removed and the externally applied field that minimizes losses is searched. This is done using a new optimization tool (GOT) and taking advantage of multipolar expansion of the external field.
\end{abstract}

\section{INTRODUCTION}

Increasing power efficiency is the main objective of power electronic designers. Wire related losses are a major concern in connecting conductors as well as inside transformers, especially at frequencies promoting eddy currents.

Due to its rotational invariance, losses due to skin effect of an isolate straight cylindrical wire can't be reduced. On the opposite, if the cross section of the wire is rectangular, external pieces of material can modify the field and the current repartition in a way such that losses are significantly reduced. The goal of this article is to find the external field shape that minimizes losses in this wire.

\section{LOSSES REDUCTION IN COPPER FLAT RECTANGULAR SHAPED CONDUCTOR}

A straight rectangular cross section wire made of copper is considered (Fig. 1). It is supplied by a $1 \mathrm{~A}_{\mathrm{eff}} 100 \mathrm{kHz}$ current.

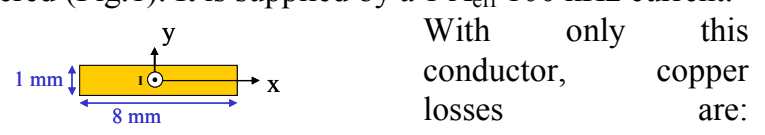

Fig.1. Rectangular shaped conductor $\quad P=6.9 \mathrm{~mW} / \mathrm{m}$.

Previous studies [1] using FEM software Flux2D [2] showed that, with two pieces of ideal ferrite $\left(\mu_{r}=2300\right.$ like 3 C90) put close to the wire as shown in Fig.2, copper looses can be reduced by $22 \%(P=5.34 \mathrm{~mW} / \mathrm{m})$

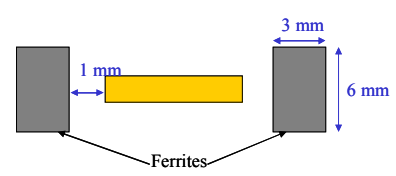

Fig.2. Losses reduction configuration

Ferrite modifies magnetic field around the copper and current density inside. To look for the minimum of losses, ferrite is replaced by two external current sources (Fig. 3): one in phase with wire total current, the other one in quadrature with it, in order to create an adjustable external inductor field. This field can be decomposed in Fourier series. For symmetry reasons, current sources only include even harmonics:

$$
\begin{array}{r}
I_{c}=I\left(1+\sum_{k=1}\left(a_{2 k}+i b_{2 k}\right) \cos (2 k)\right) \\
\text { III. OPTIMIZATION PROCESS }
\end{array}
$$

The FEM software is coupled with GOT (Global Optimization Toolbox) to achieve optimization. The method used is based on the creation of response surfaces [3] and a genetic algorithm is finally used.

\section{B. Limited Search Area}

Solution space is a huge one so optimization process needs a limited search area. In order to find a realistic one, field obtained in fig. 2 is split in an emitted part and a received one, following a method presented in [4]. External field is then created only by current densities, flowing axially in the cylinders (fig.3), which first coefficient values are:

$$
n=2, a_{2}=1.23410^{5}, b_{2}=807
$$

\section{OPTIMIZATION RESULTS}

Optimization is managed with only field harmonic 2 (coefficients $a_{2}$ and $b_{2}$ ). Losses have been reduced by $30 \%$ $(P=4.9 \mathrm{~mW} / \mathrm{m})$. Comparing current densities of wire alone (fig.4) and of field submitted wire (fig.5) it appears that peaks are lower and current is more uniform in the last one.

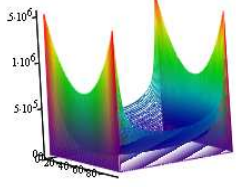

Fig.4. Initial Current density

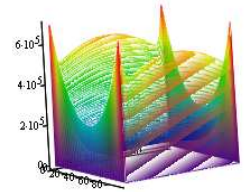

Fig.5. Current density (Optimized case)
Due to the 8 ratio of rectangle sides, currents are not easy to represent. Square representation has been preferred.

\section{A. Global Optimization Toolbox}

Optimization with a higher number of field components will be presented in final article. Obtained field and currents densities will be analyzed.

\section{REFERENCES}

[1] J. Montarros, "Drainage du flux magnétique dans les transformateurs Planar HF", Master of research,, INPG, June 2005

[2] Flux, Cedrat, 10 Chemin de Pré Carré-ZIRST, 38246 Meylan, France. http://www.cedrat.com

[3] M.C. Costa, M.L.P. Filho, Y. Marechal, J.L. Coulomb, J.R. Cardoso, "Optimization of Grounding Grids by Response Surfaces and Genetic Algorithms", IEEE Tans. Magn., vol.39, Issue 3, Part 1, pp.1301-1304, May 2003

[4] X. Margueron, J.P. Keradec T.P. Anh, O. Chadebec, G. Meunier "Applying, Canceling and Identifying the Magnetic Field Received and Emitted by a 2D Plan System", in Proc. CEFC, Miami, USA, 2006 